\title{
Increasing numbers of wintering forest birds in Swedish Lapland 1986-2017 show stronger correlations with forest development than with local weather
}

\section{Ökande antal övervintrande skogsfåglar i Lappland 1986-2017 visar starkare samband med skogens utveckling än lokalt väder}

\author{
Björn Ferry', Håkan Rune², Ulf Andersson³ \& Martin Green ${ }^{4}$ \\ 'Höjdvägen 24G, 92331 Storuman, Sweden | bjorn@bjornferry.com ${ }^{2}$ Höjdvägen 7G, 92331 Storuman, Sweden | hakan. \\ rune@storuman.se ${ }^{3}$ Furuvägen 12, 92332 Storuman, Sweden | uffe4705@hotmail.se ${ }^{4}$ Department of Biology, Lund \\ University, Ecology Building, 22362 Lund, Sweden | martin.green@biol.lu.se
}

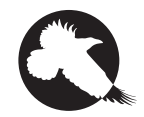

AFTER A LONG period of decline, the number of forest birds has increased in Sweden in recent decades. Whether this trend is due to an increase in forested area, forest quality, climate change, or a combination of these factors, remains unclear. Here, we compared forest bird data from a local winter point count route around Storuman in Swedish Lapland between 1986 and 2017, with the development of regional forest composition and local weather conditions. We suggest that rather than changes in average annual, winter, or summer local temperatures or precipitation, the main drivers behind increasing numbers of wintering forest birds in this part of Sweden are an increase in the area of denser forest and dead wood volume, and a decrease in open ground area without forest vegetation. While there may be supplementary explanations behind the increasing numbers of forest birds, such as reduced agriculture, decreasing local human population, or stronger photosynthesis, our results indicate that local land use has been favourable for forest birds in recent decades in this area.

Keywords: climate change | Community Temperature Index | forest variables | point counts | long-term censusing 


\section{Introduction}

Biodiversity loss is a possible threat to humanity's future (Cardinale et al. 2012). From 1970 to 2014, population sizes of mammals, birds, fish, reptiles, and amphibians around the globe declined by on average $60 \%$ (WWF 2018). A global key question is how we can manage land use so that it contributes to the well-being of humans, without jeopardizing the rest of life on Earth.

In Sweden, even-aged silviculture has been the most common forestry practice since the middle of the $20^{\text {th }}$ century (Lundmark et al. 2013). After debating the environmental effects of this practice for decades, the latest Swedish Forestry Act of 1993 stated that environmental and wood production targets should be equally important (Bush 2010). Stronger environmental targets led to the development of current certification standards, and about $60 \%$ of Sweden's productive forest has been certified during the last 20-25 years (PEFC 2019, FSC 2019). These standards aim at improving conditions for biodiversity by, for example, saving groups of trees and dead wood, and creating high stumps during harvesting. However, several studies have shown that the levels of tree retention, volume of dead wood created etc. within today's certification systems are too low to maintain a more natural biodiversity within managed forests, although they do improve conditions compared to not taking these actions (Söderström 2009, Andersson et al. 2015, Odsen et al. 2018, Basile et al. 2019).

Birds are a good proxy for overall biodiversity, as they are easy to study, well-known, and high in the food chain. A rich birdlife is likely to reflect a rich biodiversity at a general level (Roberge \& Angelstam 2006, Pakkala et al. 2014), and the number of breeding bird species in Sweden has increased continuously since 1850 (Haas et al. 2014). European bird distributions are expected to shift northwards and upwards in altitude due to the ongoing global warming (Barbet-Massin et al. 2012, Virkala \& Lehikoinen 2017). Warming can affect bird community composition at local and national levels relatively rapidly (Devictor et al. 2008, Godet et al. 2011, Lindström et al. 2013, Lehikoinen et al. 2016, Lindström 2018).

While the number of breeding bird species in Sweden has increased at a slow but constant rate since $185^{\circ}$ (Haas et al. 2014), the abundance of forest birds has most likely been declining for a long period in Sweden (Green et al. 2019). However, during the last 20 years
(1998-2018), general forest bird abundance has increased (Green et al. 2019). This development coincides with the implementation of the latest Swedish Forest Act from 1993. Nevertheless, it remains to be tested whether the positive development is due to increased forested area, forest quality, climate change, or a combination of these factors (Ram et al. 2017).

Here we analyse data for birds breeding in forest habitats, but the data is collected during winter time. Data are from a local winter point count route around Storuman in Swedish Lapland between 1986 and 2017, and we compare bird data with the development of regional forest composition and local weather conditions in an attempt to shed more light on this question.

Because most bird species that breed in Sweden spend a large part of the year in other parts of the world, it is best to analyse the effects of changes in Swedish land use and climate on birds that are resident in the country. The absolute majority of the forest bird species included in this analysis do spend the whole year in Sweden. Furthermore, most of them also spend the whole year within the same region, even though they probably use areas closer to human settlements in winter, hence making them easier to count. We also included a few (five out of 35) species that are mostly migratory. The majority of the individuals belonging to the latter species breed in Sweden but leave the country during winter. These species are interesting to include here as they may be more likely to spend the winter at northerly latitudes in a warmer climate. The number of individuals of these species was however very low during the study period.

\section{Methods}

\section{BIRD COUNTS}

We analysed bird data from a local winter point count route around Storuman $\left(65^{\circ} 06^{\prime} \mathrm{N} 17^{\circ} \mathrm{O} 7^{\prime} \mathrm{E}\right)$ in Swedish Lapland collected between 1986 and 2017. Winter point counts have been one of the methods within the national bird monitoring scheme in Sweden since 1975 (www.fageltaxering.lu.se). The bird data used here was collected as a small part of the national bird monitoring and not specifically for analysing the questions addressed here. 
A point count route comprises 20 points, placed at such distance from each other that counting an individual bird twice is prevented or at least minimised. The surveyor choses where to put the route and the points. From each point, the observer counts all birds seen and heard during exactly five minutes. The routes are surveyed up to five times each winter at about the same dates and starting hours every year. Counting periods during winter are October, November, late December or early January, February and March.

The route analysed here has been surveyed on five occasions every winter since 1986. As we wanted to analyse wintering birds breeding in forest habitats, we omitted the data collected in October. During that month there are still varying numbers, sometimes higher numbers, of migrants in the area that do not stay during the winter. Data from the remaining four surveys (November-March) were summed to represent the data for each winter. This means that bird data for the winter of 1986 (which we use to refer to the winter of 1986/1987), consists of data collected from November 1986 to March 1987 and so on. In total, data from 128 surveys between 1986 and 2017 were included.

The same two observers, Håkan Rune and Ulf Andersson, have covered the route every year, although HR has been the main surveyor at all times. The route is a little over $90 \mathrm{~km}$ long with the points well spread, see Figure 1. Half or more (10-12 per year) of the points are located near bird feeders. Overall, the number of feeding stations along the route have been rather constant during the period.

\section{FOREST VARIABLES}

We compared bird count results with regional forest variables using data from the Swedish National Forest Inventory (SNFI, www.slu.se/centrumbildningar-och-projekt/riksskogstaxeringen), covering Västerbottens Lappmark in which Storuman is situated centrally. The productive forest in Västerbottens Lappmark covers about $18,000 \mathrm{~km}^{2}$, that is one third of the overall area of Västerbotten County $(54,664$ $\mathrm{km}^{2}$ ). Due to the sampling routine within the SNFI we used five-year moving averages for the forest variables. Hence, forest data representing 1986 in our analyses are actually the average for the five years leading up to 1986 , i.e. 1982-1986, and so on. Data from the SNFI covers all productive forest outside of protected areas. We used four variables representing different successional stages as proxies for forest age. These were the area of open ground without proper forest vegetation (outcrops with very few trees as well as clear-cuts where the forest recently had been removed), young forest (planted forest $0-30$ years old), middle-aged forest (forest 30-70 years old) and forest ready for cutting (forest at least 70 years old, but most probably even older in these parts of Sweden). We also included old-growth forest (>140 years of age) area, area of older forest rich in deciduous trees ( $>80$ years old), standing volume of wood, and the volume of hard dead wood per ha as variables.

\section{WEATHER DATA}

We correlated bird count results with temperature and precipitation data from Gunnarn weather station, accessed through the Swedish Meteorological and Hydrological Institute (SMHI) open database (http:// opendata-download-metobs.smhi.se). Gunnarn weather station is located $4 \mathrm{~km}$ from the nearest, and $30 \mathrm{~km}$ from the farthest, bird count point.

Based on monthly average values, we calculated mean annual values for the period April-March. The annual mean value for 1986 was hence calculated from temperatures in April 1986 through March 1987. Summer mean temperatures were calculated for the period April to August each year, and winter temperatures for the period November to March each winter. We calculated mean precipitation values in the same way. There was no data for February 1992 from Gunnarn. In this case, we used data from the now closed (2004) weather station in Stensele instead, which is located even closer to the points on the route $(1 \mathrm{~km}$ from the nearest, and $24 \mathrm{~km}$ from the farthest, bird count point). The weather station in Gunnarn was moved a short distance in 2013, it is now situated 29 meters higher in altitude than before. This may affect both temperature and precipitation somewhat, but should not change any overall patterns.

\section{ANALYSES}

We analysed changes in bird abundance and species richness as well as forest and weather variables during the period with Spearman's rank correlations (Spearman 1904, Daniel 1990). We also used Spearman's rank correlations to analyse bird abundance, as well as species richness, in relation to forest and weather variables. All statistical analyses were performed in Excel 2016. 


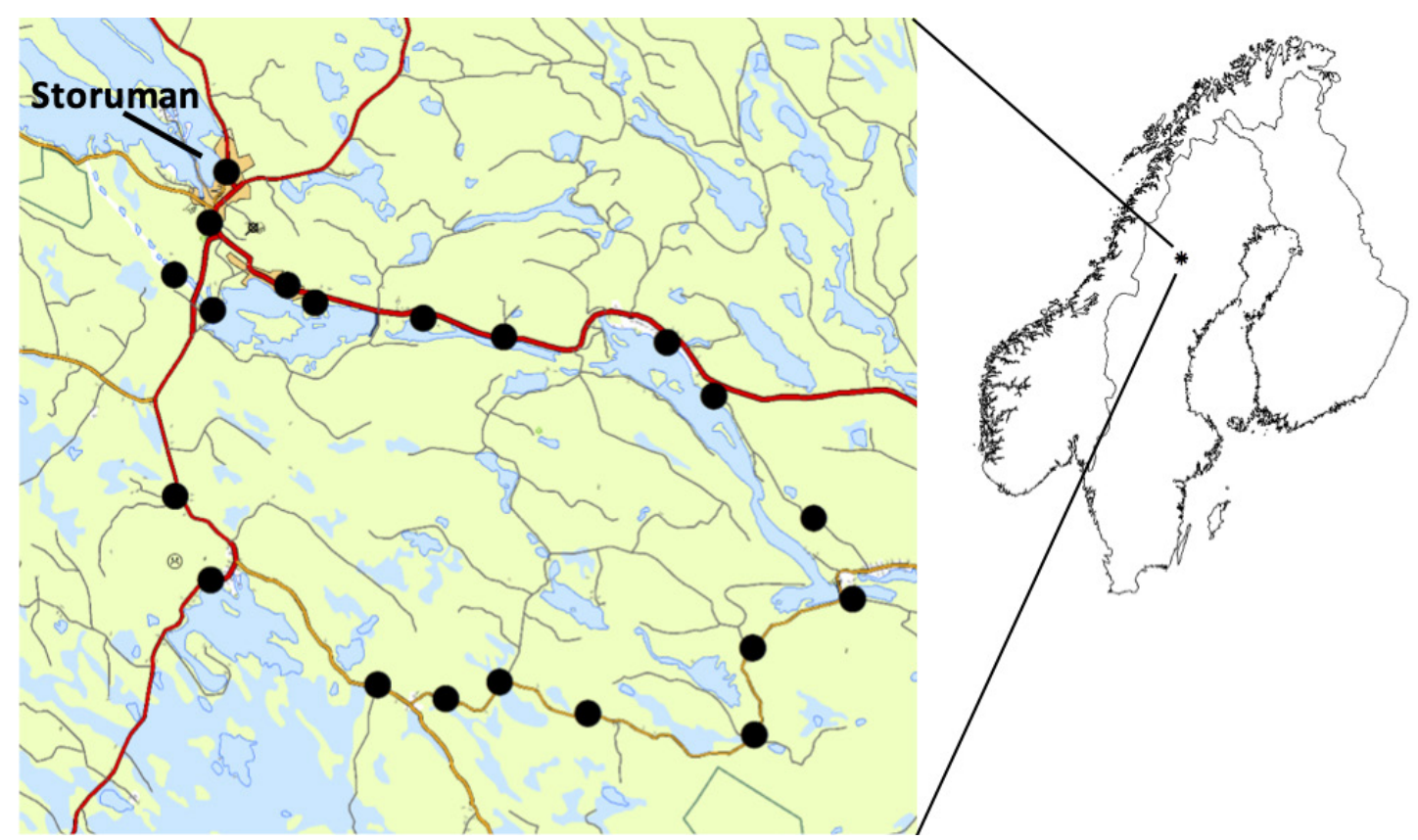

FIGURE 1. Map of the bird survey route (left) and where the route is situated in the northern part of Sweden (right). At each point (black dot), all observed birds were counted during five minutes during each survey.

- Karta över den aktuella punktrutten (till vänster) och ruttens läge i norra delen av Sverige (till höger). Vid varje punkt (svart prick) räknades alla observerade fåglar under fem minuter vid varje inventering.

In our analyses, we looked at birds directly connected to forest habitats during the breeding season, hereafter forest birds. These birds may or may not use forest habitats during the winter. We do not analyse winter habitat use, and winter habitat use is not relevant for the questions we ask here. We classified forest birds in the same way as Ram et al. (2017). In our case, this meant that we initially classified 35 species observed along the route as forest birds (see Appendix 1). Here we lumped all identified Red and Parrot Crossbills Loxia curvirostra and Loxia pytyopsittacus together with unidentified Red/Parrot Crossbills into one taxon, i.e. Crossbills, in order to minimize possible effects of the identification pitfalls regarding this group of birds (see Martin et al. 2019). In addition, we included two raptors (Golden Eagle Aquila chrysaetos and Northern Goshawk Accipiter gentilis) and two owls (Northern HawkOwl Surnia ulula and Eurasian Pygmy Owl Glaucidium passerinum) among the forest birds. Hence, the group of forest birds comprised 39 species in total (Appendix 1).

We also analysed a group of forest specialist species. They are connected to more varied and natural forests with a high degree of structural complexity (see Ottvall et al. 2008). There are nine forest specialist species that has been seen at least once along the route: Western Capercaillie Tetrao urogallus, Black Woodpecker Dryocopus martius, Lesser Spotted Woodpecker Dryobates minor, Eurasian Three-toed Woodpecker Picoides tridactylus, Willow Tit Poecile montanus, Grey-headed Chickadee Poecile cinctus, Eurasian Treecreeper Certhia familiaris, Siberian Jay Perisoreus infaustus and Pine Grosbeak Pinicola enucleator.

In addition to analysing the bird data as they were counted in the field, we calculated the Community Temperature Index (CTI; Devictor et al. 2008) for each winter, and then analysed changes in CTI over the period as well as correlations between CTI and weather variables. CTI is a measure of the composition of the bird community, here at the local level as we base the calculations on forest bird numbers counted along the single route involved. CTI can be calculated for any geographical area, such as route, province or country, as long as you have data covering the whole bird community or a representative sample of the whole bird 
community. CTI shows changes in the relative abundances of birds with colder or warmer distributions. If birds with warmer distribution areas become relatively more common, CTI will increase. If birds with colder distribution areas become relatively more common, CTI will decrease. Hence, CTI shows changes in bird community composition (Devictor et al. 2008)

CTI is calculated as the average Species Temperature Index (STI) of all bird individuals (observed ones or estimated total population sizes). The STI, in turn, is the average temperature during the breeding season in the European breeding area of the species. Here we used the average temperature during April-August, in turn averaged over the period 1961-2008 for the breeding distribution of each species. We used temperature data from the Worldclim database (http://www.worldclim.org) and breeding distributions from the European breeding bird atlas (Hagemeijer \& Blair 1997) in our calculations of STI. A species with a northern breeding distribution will have a relatively low STI. A species with a southern distribution will have a relatively higher STI. For more details, see Devictor et al. (2008) and Lindström et al. (2013). We calculated a CTI for the route for each winter based on the total number of

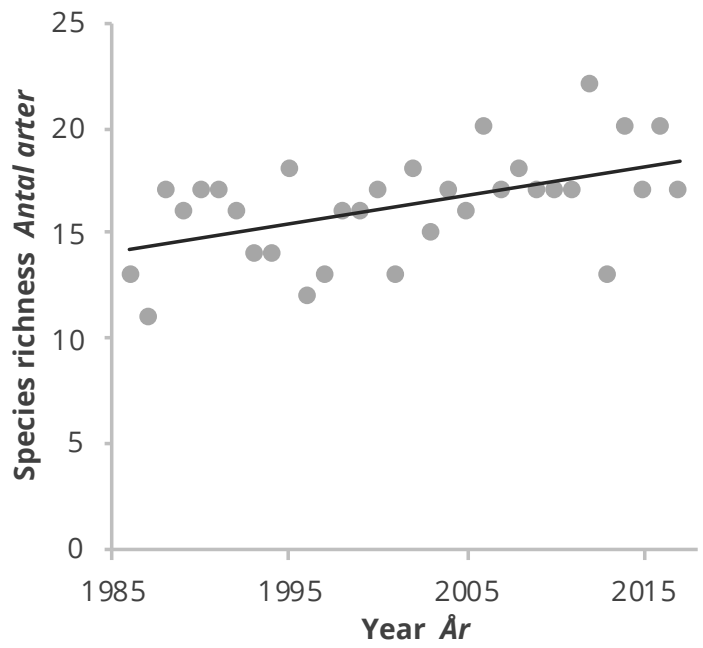

FIGURE 2. Number of forest bird species observed along the route per winter (total number during four surveys per winter, November-March) 1986-2017. The trend line represents a linear regression (though analyses are made with non-parametric correlations). - Antal observerade skogsfågelarter längs rutten per vinter (fyra inventeringar/vinter, nov-mar) 1986-2017. Trendlinjen visar en linjär regression (fast analyserna är gjorda med icke-parametrisk korrelation). forest bird individuals observed during the four periods. CTI is expressed in degrees Celsius $\left({ }^{\circ} \mathrm{C}\right)$.

\section{Results}

\section{CHANGES IN BIRD ABUNDANCE AND BIRD COMMUNITY COMPOSITION}

Over the years, 39 different forest bird species were observed along the route. The number of registered forest bird species per winter increased during the period (Figure $2, r_{s}=0.50, p<0.01$ ). There were a few new forest species turning up in the area during the study period. Among these were the Eurasian Nuthatch Sitta europea, seen for the first time in 1995 and observed annually since 2007; the Grey-headed Woodpecker Picus canus, not seen until 2002 but seen during most years thereafter; and Spotted Nutcracker Nucifraga caryocatactes, first seen in 2008 and since then observed during several years. There were no forest species that disappeared from the area during the study period.

A total of 15,907 forest bird individuals were observed over the years. Total numbers of observed forest birds along the route per winter are shown in Appen-

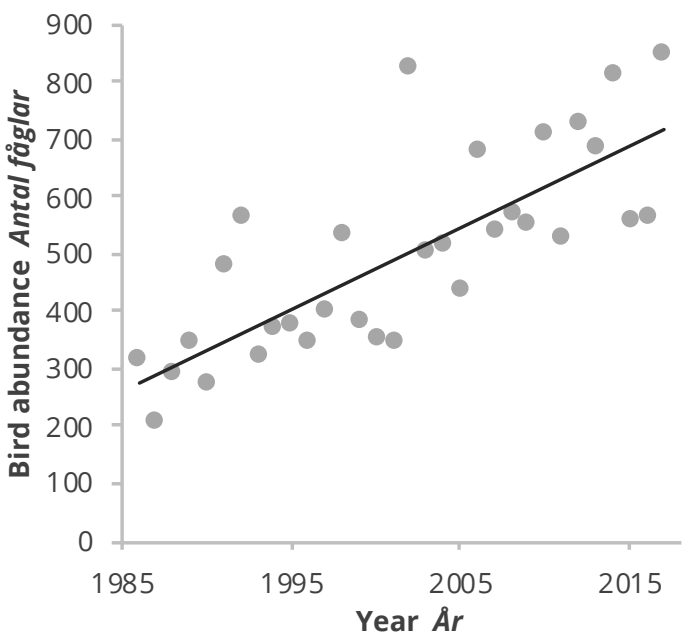

FIGURE 3. Bird abundance along the route per winter (sum of four surveys per winter, November-March) 1986-2017. The trend line represents a linear regression (though analyses are made with non-parametric correlations).

- Totala antalet fågelindivider av de utvalda skogsfågelarterna längs rutten per vinter (summan av fyra inventeringar per vinter, november-mars) 1986-2017 (fast analyserna är gjorda med icke-parametrisk korrelation). 


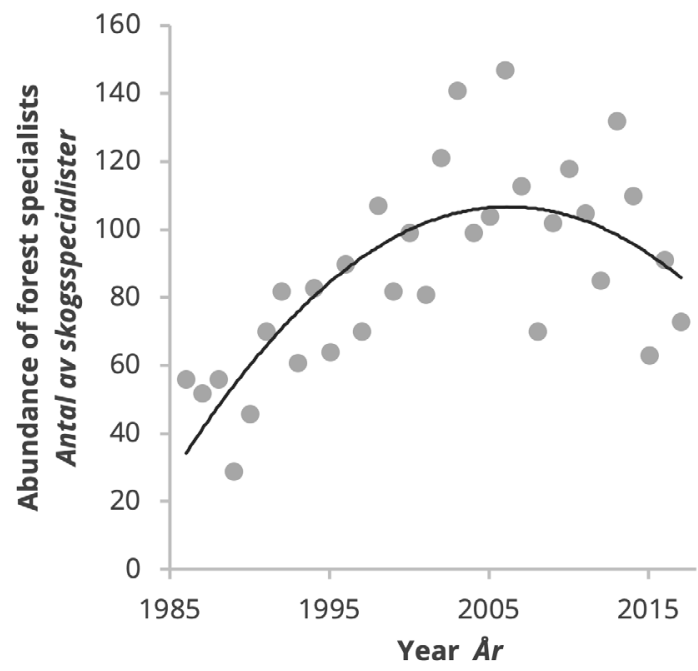

FIGURE 4. Abundance of forest specialist species counted along the route per winter (sum of four surveys per winter, November-March) 1986-2017. The trend line represents a quadratic function (though analyses are made with non-parametric correlations).

- Totalantalet individer av specialiserade skogsfågelarter längs rutten per vinter (fyra inventeringar per vinter, november-mars) 1986-2017. Trendlinjen visar en kvadratisk funtion (fast analyesrn är gjorda med icke-parametrisk korrelation).

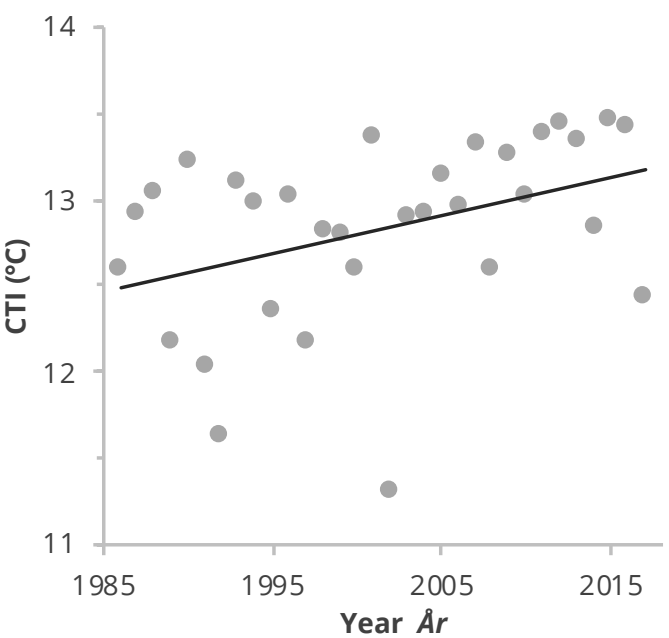

FIGURE 5. Average Community Temperature Index (CTI) per winter along the route 1986-2017. The trend line represents a linear regression (though analyses are made with nonparametric correlations).

- Fågelsamhällets genomsnittliga temperaturindex (CTI) per vinter längs rutten 1986-2017. Trendlinjen visar en linjär regression (fast analyserna är gjorda med icke-parametrisk korrelation). dix 1. The abundance of observed forest birds increased significantly 1986-2017 (Figure 3, $\mathrm{r}_{\mathrm{s}}=0.81, \mathrm{p}<0.001$ ). The most common forest birds observed along the route were Great Tit Parus major, Eurasian Bullfinch Pyrrhula pyrrhula, Willow Tit, and Bohemian Waxwing Bombycilla garrulus. These species were all observed with more than 1,000 individuals in total during the period, and made up 58-88\% of all observed forest birds per winter. The proportions between the most common species and the less common species varied between years, but for the entire period the proportions did not change. We found increasing numbers of the four most common species $\left(r_{s}=0.82, p<0.001\right)$, and the remaining 35 of the less common species also increased $\left(r_{s}=0.37\right.$, $\mathrm{p}<0.05$ ).

Between two and six forest specialist species were seen along the route every winter. During the whole period we found no significant change in the number of forest specialist species $\left(r_{s}=0.01, p>0.10\right)$ Willow Tit was by far the most common specialist bird and the only one observed every year. Siberian Jay was observed every year except one (2014). The other specialist species were observed more irregularly. In total, the number of forest specialist birds increased sharply from 1989 to 2006 , but has since decreased in numbers again. However, seen over the whole study period, the number of forest specialist birds has increased (Figure $4, r_{s}=0.58, p<0.01$ ).

Bird community composition, measured as average CTI per winter, varied between $11.3^{\circ} \mathrm{C}$ and $13.5^{\circ} \mathrm{C}$. CTI increased significantly over the study period (Figure 5 , $\left.\mathrm{r}_{\mathrm{s}}=0.44, \mathrm{p}<0.05\right)$. This means that the proportions of forest bird individuals belonging to species with warmer breeding distributions became relatively more common during the 32 study winters compared to forest birds belonging to species with colder breeding distributions.

\section{CHANGES IN EXTERNAL FACTORS}

\section{Forest variables}

We show Spearman's rank correlations between forest variables in Västerbottens lappmark and time over the period 1986-2017 in Table 1. We found decreasing areas of open ground and young forest, while the area of more fully grown forest increased. This increase mainly regarded middle-aged forest (30-70 years of age), while the area of forest ready for clear-cutting ( $>70$ years old) decreased. The old-growth forest ( $>140$ years) area decreased during the first ten years, followed by an 
TABLE 1. Spearman's rank correlations between forest variables and year for Västerbottens lappmark 1986-2017. $r_{S}$ is the Spearman's rank correlation coefficient. Statistical significance (sign.) is indicated by asterisks, where ${ }^{*} p<0.05,{ }^{* *} p<0.01,{ }^{* * *} p<0.001$.

- Spearmans rangkorrelationer mellan skogsvariabler och år för Västerbottens lappmark 1986-2017. $r_{s}$ är Spearmans rangkorrelationskoefficient. Statistisk signifikans (sign.) visas av asterisker där * $p<0,05,{ }^{* *} p<0,01,{ }^{* * *} p<0,001$.

\begin{tabular}{|c|c|c|}
\hline Forest variable Skogsvariabel & $r_{s}$ & Sign. \\
\hline Open ground, area Öppen mark, yta & -0.95 & $\star \star \star *$ \\
\hline Young forest (0-30 years), area Ung skog (0-30 år), yta & -0.62 & $\star * \star$ \\
\hline Middle-aged forest (30-70 years), area Medelålders skog (30-70 år), yta & 0.95 & $\star * \star$ \\
\hline Forest ready for cutting (>70 years), area Avverkningsmogen skog (>70 år), yta & -0.80 & $\star \star \star$ \\
\hline $\begin{array}{l}\text { Fully grown forest (middle-aged + ready for cutting; }>30 \text { years), area } \\
\text { Fullt uppvuxen skog (medelålders + avverkningsmogen; }>30 \text { år), yta }\end{array}$ & 0.41 & * \\
\hline Old forest (>140 years), area Gammal skog (>140 år), yta & 0.43 & * \\
\hline $\begin{array}{l}\text { Older forest, rich in deciduous trees (>80 years), area } \\
\text { Äldre lövträdsrik skog (>80 år), yta }\end{array}$ & -0.68 & $\star * \star$ \\
\hline Standing volume of wood in fully grown forest Stående skogsvolym i fullt uppvuxen skog & 0.96 & $\star \star \star$ \\
\hline Dead wood, volume Död ved, volym & 0.87 & $\star \star \star$ \\
\hline
\end{tabular}

increase during the next ten years, and finally remaining at about the same level in the end of the period, resulting in a slight overall increase over the whole period. During the study period the area of older forest $(>80$ years old) rich in deciduous trees decreased, while the standing volume of wood increased continuously, i.e. the forests became denser. The volume of dead wood also increased during the period.

\section{Weather variables}

We found no significant changes in local average temperature or precipitation during the period 1986-2017, irrespective of whether we analysed annual, winter, or summer averages (Table 2).

\section{CORRELATIONS BETWEEN BIRDS AND EXTERNAL FACTORS}

\section{Birds and forest variables}

We found stronger correlations between bird variables and forest variables than between bird variables and weather variables (Appendix 2). The most relevant relationships between bird variables and external factors are shown in Figure 6.

The forest species richness significantly increased with increasing area of middle-aged forest, standing volume of wood, volume of dead wood and increasing area of old-growth forest, but significantly decreased with increasing area of open ground and forest ready for cutting, and tended to do so for older forest rich in deciduous trees (Figure 6, Appendix 2).

The pattern was similar for abundance of forest birds, which significantly increased with area of middle-aged forest, standing volume of wood, and volume of dead wood, but significantly decreased with increasing area of open ground, forest ready for cutting, and older forest rich in deciduous trees (Figure 6, Appendix 2). We found a tendency for an increased number

TABLE 2. Spearman's rank correlations between weather variables from Gunnarn and year 1986-2017. $r_{\text {s }}$ is the Spearman's rank correlation coefficient. The Spearman's rank correlation was not statistically significant for any of the weather variables.

- Spearmans rangkorrelationer mellan vädervariabler från Gunnarn och år 1986-2017. $r_{\text {s }}$ är Spearmans rangkorrelationskoefficient. Ingen av vädervariablerna uppvisade en statistiskt signifikant korrelation med år.

\begin{tabular}{lc}
\hline Weather variable Vädervariabel & $r_{\mathrm{s}}$ \\
\hline $\begin{array}{l}\text { Annual temperature (April-March) } \\
\text { Arstemperatur (april-mars) }\end{array}$ & 0.18 \\
$\begin{array}{l}\text { Winter temperature (November-March) } \\
\text { Vintertemperatur (november-mars) }\end{array}$ & 0.05 \\
$\begin{array}{l}\text { Summer temperature (April-August) } \\
\text { Sommartemperatur (april-augusti) }\end{array}$ & 0.18 \\
$\begin{array}{l}\text { Annual precipitation (April-March) } \\
\text { Arsnederbörd (april-mars) }\end{array}$ & -0.10 \\
$\begin{array}{l}\text { Winter precipitation (November-March) } \\
\text { Vinternederbörd (november-mars) } \\
\text { Summer precipitation (April-August) } \\
\text { Sommarnederbörd (april-augusti) }\end{array}$ & -0.25 \\
\hline
\end{tabular}




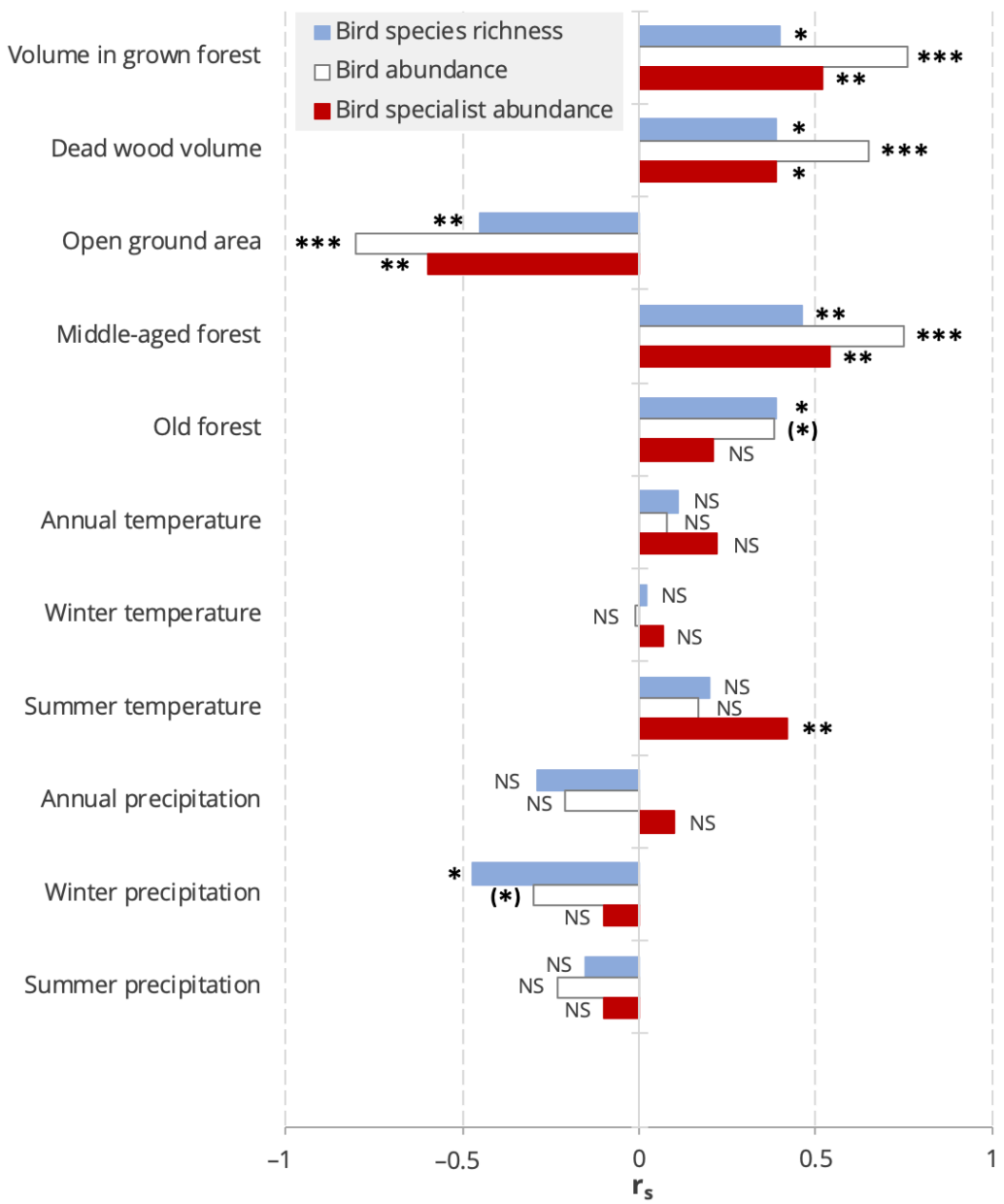

FIGURE 6. Spearman's rank correlations between bird variables and external factors. $r_{s}$ is the Spearman's rank correlation coefficient. Statistical significance is shown by asterisks where $* p<0.05$, ${ }^{* *} p<0.01,{ }^{* * *} p<0.001 .\left({ }^{*}\right)$ indicates tendencies that were not statistically significant but with $p<0.10$. NS=not significant.

- Spearmans rangkorrelationer mellan fågelvariabler och yttre faktorer. $r_{s}$ är Spearmans rangkorrelationskoefficient. Statistisk signifikans visas av asterisker där * $p<0,05,{ }^{* *} p<0,01,{ }^{* * *} p<0,001$. (*) indikerar tendenser som inte är statistiskt signifikanta, men med $p<0,10$. NS=inte signifikant.
Birds and weather variables We found no significant correlations between temperature and wintering forest bird individuals or number of forest bird species in general, regardless of whether we looked at average annual, winter, or summer temperatures. However, higher summer temperatures significantly correlated with an increase of the numbers of forest specialists (Figure 6, Appendix 3).

Annual and summer precipitation did not affect wintering bird numbers along the route. The specialists did not show any significant correlations with precipitation, but the number of forest bird species increased significantly and the forest bird abundance showed a tendency to increase when winter precipitation decreased (Figure 6, Appendix 3).

Bird community composition We found no significant correlations between CTI and observed numbers of forest species, forest specialists, or abundance (all $r_{s}$ of forest birds with increasing area of old-growth forest (Figure 6, Appendix 2).

The abundance of forest specialist birds significantly increased with increasing area of middle-aged forest, standing volume of wood, and volume of dead wood, but significantly decreased with increasing area of open ground, forest ready for cutting, and older forest rich in deciduous trees. Somewhat surprisingly, the numbers of forest specialist birds did not increase with increasing area of old-growth forest (Figure 6, Appendix 2).
0.02-0.10). In general, CTI did not show any significant correlations with weather variables, save for winter precipitation, where increased precipitation correlated with decreased CTI (Table 3).

\section{Discussion}

The main driving force behind the recent decades' increase in forest birds in Sweden is uncertain. We addressed this question from a local perspective by 
measuring winter bird abundance on a local route, while looking at forest composition at a regional level. The forest development may not be exactly the same at a regional level as around the local bird route. However, changes in forest composition at a regional level should affect the bird numbers at a regional level, which to a large extent should affect local bird numbers along the survey route analysed here. Also, winter bird assemblages are most probably recruited from a larger area in the region than just locally around the actual route. Hence, there is no reason to expect that the different geographical scales for bird and forest data should drastically affect the relationships that we found.

We found that increased wintering forest bird numbers around Storuman in Swedish Lapland show stronger correlations with forest variables than with local average weather variables. At least the local weather variables we explored here did not explain the increased abundance of forest birds, neither average temperature nor precipitation. It might be that there are other weather variables that show stronger correlations with bird data, and that is something that could be addressed in coming analyses. Further, just as regional forest development data may be advantageous because of a larger recruitment area of wintering birds, using regional weather data could possibly paint a different picture. There are however no signs of that the weather at Gunnarn should be any different from the regional weather.

Some of the correlations found between forest birds and forest parameters probably have little biological significance. For example, that reduced area of older forest rich in deciduous trees would have been positive for forest birds in general is highly unlikely. Older forest rich in deciduous trees is known to be rich in birds, both in terms of number of species and abundance (Svensson et al. 1999, Poulsen 2002, Forslund 2003, Tjernberg and Svensson 2007, Rosenvald et al. 2011). On the other hand, the correlations between forest birds and decreasing areas of open ground and increasing volume of dead wood are likely to be biologically significant (Svensson et al. 1999, Poulsen 2002, Forslund 2003, Tjernberg and Svensson 2007, Rosenvald et al. 2011). The fact that the volume of dead wood is increasing is probably positive for the forest birds, as well as for biodiversity in general; several of the here recorded forest birds find nesting sites in dead wood and/or find their food in dead wood. A decreased area
TABLE 3. Spearman's rank correlations between Community Temperature Index (CTI) and weather variables 1986-2017. $r_{S}$ is the Spearman's rank correlation coefficient. Statistical significance (sign.) is shown by asterisks where ${ }^{*} p<0.05,{ }^{* *} p<0.01,{ }^{* * *} p<0.001$. NS $=$ not significant.

- Spearmans rangkorrelationer mellan fågelsamhällets temperaturindex (CTI) och vädervariabler 1986-2017. $r_{s}$ är Spearmans rangkorrelationskoefficient. Statistisk signifikans visas av asterisker där ${ }^{*} p<0,05,{ }^{* *} p$ $<0,01,{ }^{* * *} p<0,001$. NS=inte signifikant.

\begin{tabular}{lcc}
\hline Weather variable Vädervariabel & $r_{\mathrm{s}}$ & Sign. \\
\hline $\begin{array}{l}\text { Annual temperature (April-March) } \\
\text { Arstemperatur (april-mars) }\end{array}$ & 0.18 & NS \\
$\begin{array}{l}\text { Winter temperature (November-March) } \\
\text { Vintertemperatur (november-mars) }\end{array}$ & 0.07 & NS \\
$\begin{array}{l}\text { Summer temperature (April-August) } \\
\text { Sommartemperatur (april-augusti) }\end{array}$ & 0.24 & NS \\
$\begin{array}{l}\text { Annual precipitation (April-March) } \\
\text { Arsnederbörd (april-mars) }\end{array}$ & -0.27 & NS \\
$\begin{array}{l}\text { Winter precipitation (November-March) } \\
\text { Vinternederbörd (november-mars) }\end{array}$ & -0.36 & * \\
$\begin{array}{l}\text { Summer precipitation (April-August) } \\
\text { Sommarnederbörd (april-augusti) }\end{array}$ & -0.20 & NS \\
\hline
\end{tabular}

of open ground means that the area of forest is increasing, hence it seems obvious that this is beneficial for species connected to forest. Denser forests, though, are not always positive for forest birds, but the more open older forests, that were harvested in the 1950 s to 1970 s in southern Lapland, are now considerably denser middle-aged managed forests, which may be more suitable for some of the forest bird species.

Forest bird community composition, measured as CTI, changed significantly during the study period. This means that birds with warmer distribution did relatively better than birds with colder breeding distributions. Despite this we did not find any correlations between CTI and local temperature. This is at odds with the general finding that bird community composition at local and national level can change relatively rapidly in relation to changes in temperature (Devictor et al. 2008, Godet et al. 2011, Lindström et al. 2013, Lehikoinen et al. 2016, Lindström 2018).

Local species richness shows the same pattern as Haas et al. (2014) found for breeding bird species at a national scale. They showed that the number of breeding species has increased continuously in Sweden since 1850 . This finding is also in line with predictions that the number of breeding birds should decrease in southern Europe, but increase in more northerly areas 
due to the ongoing global warming (Barbet-Massin et al. 2012, Lehikoinen \& Virkkala 2016, Virkkala \& Lehikoinen. 2017). There are, however, probably no direct links between the expectations of increasing numbers of breeding species in Sweden and northern Europe at large, and our finding of an increasing number of wintering forest species locally in southern Lapland, since none of the forest species recorded along the route and included in this analysis are new in the Swedish breeding bird fauna. On the other hand, there could be such links at a more local level, i.e. if forest species previously not breeding in the region have established themselves there during the study period. This is partly supported by our data, where some forest species that were not seen during the early winters of our study were seen on a more regular basis during later years. All these species-Eurasian Nuthatch, Grey-headed Woodpecker, and Spotted Nutcracker-probably established themselves as breeding birds in the local or regional area during the study period. Hence, part of the increase in wintering forest bird species around Storuman is probably caused by an increased number of breeding forest bird species in the area.

The local development of wintering forest bird numbers around Storuman in general follow a similar pattern in Sweden as a whole during the last two decades. In total, the number of breeding bird individuals has increased in Sweden since 1998 (Green et al. 2019). Most of this increase has taken place among forest birds, while the number of individuals of species linked to agricultural areas, wetlands, coasts and mountains either decreased or remained more or less stable during the same period. It may be that the general increase of forest birds mirrors the decline among bird species linked to cultivated areas. The areas of farmland and pastures have steadily declined, and become forested as farming has ceased (Wretenberg et al. 2006). Another related explanation may be the general decrease in human population in northern rural areas. Storuman Municipality showed a population decrease of $27.2 \%$ during 1986-2017 (www.scb.se). Exactly how this decrease in local human population may have affected the local abundance of wintering forest birds remains unsure, but we can think of two different ways, apart from that smaller and smaller areas are kept open for farming. (1) A decrease in local human population size could have been beneficial for abundance of forest birds, as general and direct human pressure on the local environment decreases with fewer people around. Or it could work in an opposite way for wintering forest birds if (2) local wintering populations are more or less dependent on feeding stations provided by humans. We do not know the exact development of the number of bird feeding stations or the amount of bird food provided around Storuman during the period. Although the number of stations along the route has remained relatively similar during the period, this may or may not have been the same at a more general level in the area.

We also found increasing numbers of forest specialist birds, although there was actually a sharp increase for the first 20 years followed by a decrease during the last 12 years. The local forest specialist birds follow the national patterns fairly well. In Sweden, the number of forest specialist birds increased in 1998 to 2008, but in the last decade the positive trend has leveled off (Green et al. 2019). At the national level the positive effects of important forest parameters such as increasing area of old-growth forest, stratification, number of retention trees per ha, and dead wood volume appear to have ceased recently (Ram et al. 2017). In our study the numbers of forest specialist birds increased with increasing middle-aged forest area, standing wood volume and dead wood volume. Somewhat surprisingly, the abundance of forest specialist birds did not increase with increased old-growth forest area. Despite the fact that forest specialist birds locally did not increase with increased old-growth forest area, the future development of forest specialist birds, both locally and in Sweden at large, may be dependent on what happens to the structurally complex forests that still remain.

Our main finding is that forest bird numbers correlate more strongly with the development of the forest than with changes in local weather. However, there could be other factors at play that also vary on a time scale similar to the variation in bird numbers. We already discussed reduced agriculture and decreasing human population as potential factors; another variable that could possibly affect the variation in bird numbers is the annual strength of the photosynthesis. There is increasing support for the notion that a warmer climate and a fertilizer effect from the increasing $\mathrm{CO}_{2}$ levels in the atmosphere have made a large part of the planet greener (Keeling et al. 1996, Los 2013, Zhu et al. 2016, Munier et al. 2018, Fernández-Martínez et al. 2019). A 
sign of increasing photosynthesis at high latitudes is that the seasonal amplitude of $\mathrm{CO}_{2}$ concentrations has risen around $25 \%$ since the 1960 s, mainly due to higher temperatures (Forkel et al. 2016). If, or how, this affects the birds in some way is unknown, but might be worth to study in detail. Increasing photosynthesis will lead to more vegetation, which could lead to higher densities and numbers of primary consumers such as insects. This, in turn, would potentially provide more food for birds during the northern breeding season, resulting in higher breeding success and higher bird numbers also among wintering forest bird species.

In conclusion, since neither the average temperature nor the average precipitation has changed during the study period, these variables are less likely to explain the general increase of wintering forest birds around Storuman. However, we found strong correlations between variables measuring forest birds and denser, fully grown forests, volumes of dead wood, and decreased areas of open ground without forest vegetation. While there may be other explanations behind the increase in forest bird numbers, such as reduced agriculture, decreased human population, or stronger photosynthesis, our results indicate that local land use has been favourable for forest birds in recent decades in this area.

\section{Acknowledgements}

We thank Sören Wulff who provided the forest data, Martin Rosvall and an anonymous referee for valuable comments on earlier versions. Fredrik Haas helped us with making the maps in Figure 1.

\section{References}

Andersson J, Hjältén J \& Dynesius M. 2015. Wood-inhabiting beetles in low stumps, high stumps and logs on boreal clear-cuts: implications for dead wood management. PLoS One 10: eo118896. https://doi.org/10.1371/journal.pone.0127220

Angelstam P, Dönz-Breuss M \& Roberge J-M. 2004. Targets and tools for the maintenance of forest biodiversity - an introduction. Ecological Bulletins 51: 11-24.

Basile M, Mikusiński G \& Storch I. 2019. Bird guilds show different responses to tree retention levels: a meta-analysis. Global Ecology and Conservation 18: eoo615. https://doi.org/10.1016/j.gecco.2019.eoo615

Barbet-Massin M, Thuiller W \& Jiguet F. 2012. The fate of European breeding birds under climate, land-use and dispersal scenarios. Global Change Biology 18: 881-89o. https://doi. org/10.1111/j.1365-2486.2011.02552.x

Bush T. 2010. Biodiversity and sectoral responsibility in the development of Swedish Forestry Policy, 1988-1993. Scandinavian Journal of
History 35: 471-498. https://doi.org/10.108o/03468755.2010.528249 Cardinale BJ, Duffy JE, Gonzalez A, Hooper DU, Perrings C, Venail P, Narwani A, Mace GM, Tilman D, Wardle DA, Kinzig AP, Daily GC, Loreau M, Grace JB, Larigauderie A, Srivastava DS \& Naeem S. 2012. Biodiversity loss and its impact on humanity. Nature 486 : 59-67. https://doi.org/10.1038/nature11148

Daniel WW. 1990. Spearman rank correlation coefficient. Pp. 358-365 in: Applied Nonparametric Statistics ( $2^{\text {nd }}$ edition). PWS-Kent, Boston.

Devictor V, Julliard R, Couvet D \& Jiguetet F. 20o8. Birds are tracking climate warming, but not fast enough. Proceedings of the Royal Society B 275: 2743-2748. https://doi.org/10.1098/rspb.2008.0878

Fernández-Martínez M, Sardans J, Chevallier F, Ciais P, Obersteiner M, Vicca S, Canadell JG, Bastos A, Friedlingstein P, Sitch S, Piao SL, Janssen IA \& Peñuelas J. 2019. Global trends in carbon sinks and their relationships with $\mathrm{CO}_{2}$ and temperature. Nature Climate Change 9: 73-79. https://doi.org/10.1038/s41558-018-0367-7

Forkel M, Carvalhais N, Rödenbeck C, Keeling R, Heinmann M, Thonicke K, Zaehle S \& Reichstein M. 2016. Enhanced seasonal $\mathrm{CO}_{2}$ exchange caused by amplified plant productivity in northern ecosystems. Science 351: 696-699. https://doi.org/10.1126/science.aac4971

Forslund M. 2003. Fågelfaunan i olika skogsmiljöer - en studie på beståndsnivå. Skogsstyrelsens rapport 2003:2. Skogsstyrelsens förlag, Jönköping. Available at http://www.skogsfaglar.info/ skogsfaglarnas_miljoval.pdf.

FSC. 2019. Svensk statistik - Statistik och Fakta. Retrieved 2 April 2019 from https://se.fsc.org/se/fscs-betydelse/statistik-och-fakta.

Godet L, Jaffré M \& Devictor V. 2011. Waders in winter: long-term changes of migratory bird assemblages facing climate change. Biology Letters 7: 714-717. https://doi.org/10.1098/rsbl.2011.0152

Green M, Haas F \& Lindström Å. 2019. Monitoring population changes of birds in Sweden. Annual report for 2018. Department of Biology, Lund University, Lund. 92 pp. Available at https://www. fageltaxering.lu.se/resultat/arsrapporter.

Haas F, Barbet-Massin M, Green M, Jiguet F \& Lindström Å. 2014. Species turnover in the Swedish bird fauna 1850-2009 and a forecast for 2050. Ornis Svecica 24: 106-128. https://doi.org/10.3408o/ os.v24.19602

Hagemeijer WJM \& Blair MJ (eds). 1997. The EBCC atlas of European breeding birds: their distribution and abundance. T \& AD Poyser, London.

Keeling C, Chin J \& Whorf T. 1996. Increased activity of northern vegetation inferred from atmospheric $\mathrm{CO}_{2}$ measurements. Nature 382: 146-149. https://doi.org/10.1038/382146ao

Lehikoinen A \& Virkkala R. 2016. North by north-west: climate change and directions of density shifts in birds. Global Change Biology 22: 1121-1129. https://doi.org/10.1111/gcb.13150

Lehikoinen A, Foppen RPB, Heldbjerg H, Lindström Å, van Manen W, Piirainen S, van Turnhout CAM \& Butchart SHM. 2016. Largescale climatic drivers of regional winter bird population trends. Diversity and Distributions 22: 1163-1173. https://doi.org/10.1111/ ddi. 12480

Lindström Å, Green M, Paulson G, Smith HG \& Devictor V. 2013. Rapid changes in bird community composition at multiple spatial scales in response to recent climate change. Ecography 36: 313-322. https://doi.org/10.1111/j.1600-0587.2012.07799.x

Lindström Å. 2018. Så påverkas fåglarna. Bi-lagan 1/2018: 11-13. Available at https://www.fageltaxering.lu.se/sites/default/files/ files/Uppsatser/bi-lagan-faglarochklimat.pdf.

Los SO. 2013. Analysis of trends in fused AVHRR and MODIS NDVI data for 1982-2006: Indication for a $\mathrm{CO}_{2}$ fertilization effect in global vegetation. Global Biogeochemical Cycles 27: 318-330. https:// doi.org/10.1002/gbc.20027 
Lundmark H, Josefsson T \& Östlund L. 2013. The history of clear-cutting in northern Sweden - driving forces and myths in boreal silviculture. Forest Ecology and Management 307: 112-122. https://doi.org/10.1016/j.foreco.2013.07.003

Martin R, Rochefort J, Mundry R \& Segelbacher G. 2019. Delimitation of call types of Red Crossbill (Loxia curvirostra) in the Western Palearctic. Écoscience 26: 177-194. https://doi.org/10.1080/ 11956860.2018 .1564483

Munier S, Carrer D, Planque C, Camacho F, Albergel C \& Calvet J-C. 2018. Satellite leaf area index: global scale analysis of the tendencies per vegetation type over the last 17 years. Remote Sensing 10: 424. https://doi.org/10.3390/rs10030424

Odsen SG, Pinzon J, Schmiegelow FKA, Acorn J \& Spence JR. 2018. Boreal songbirds and variable retention management: a fifteen-year perspective on avian conservation and forestry. Canadian Journal of Forest Research 48: 1495-1502. https://doi.org/10.1139/ cjfr-2018-0203

Ottvall R, Edenius L, Elmberg J, Engström H, Green M, Holmqvist N, Lindström Å, Tjernberg M \& Pärt T. 2008. Populationstrender för fågelarter som häckar i Sverige. Naturvårdsverket rapport 5813. Available at https://www. naturvardsverket.se/Om-Naturvardsverket/Publikationer/ ISBN/5800/978-91-620-5813-5/.

Pakkala T, Lindén A, Tiainen J, Tomppo E \& Kouki J. 2014. Indicators of forest biodiversity: which bird species predict high breeding bird assemblage diversity in boreal forests at multiple spatial scales? Annales Zoologici Fennici 51: 457-476. https://doi. org/10.5735/086.051.0501

PEFC. 2019. PEFC-certifierad Areal Sverige. Statistik. Retrieved 2 April 2019, from http://pefc.se/statistik/.

Poulsen BO. 2002. Avian richness and abundance in temperate Danish forests: tree variables important to birds and their conservation. Biodiversity \& Conservation 11: 1551-1566. https://doi. org/10.1023/A:1016839518172

Ram D, Axelsson A-L, Green M, Smith HG \& Lindström Å. 2017. What drives current population trends in forest birds - forest quantity, quality or climate? A large-scale analysis from northern Europe. Forest Ecology and Management 385: 177-188. https://doi. org/10.1016/j.foreco.2016.11.013
Roberge J-M \& Angelstam P. 20o6. Indicator species among resident forest birds - a cross-regional evaluation in northern Europe. Biological Conservation 130: 134-147. https://doi.org/10.1016/j. biocon.2005.12.008

Rosenvald R, Lõhmus A, Kraut A \& Remm L. 2011. Bird communities in hemiboreal old-growth forests: the role of food supply, stand structure, and site type. Forest Ecology and Management 262: 1541-1550. https://doi.org/10.1016/j.foreco.2011.07.002

Spearman C. 1904. The proof and measurement of association between two things. American Journal of Psychology 15: 72-101. https://doi.org/10.2307/1422689

Svensson S, Svensson M \& Tjernberg M. 1999. Svensk Fågelatlas. Vår Fågelvärld supplement 31. Sveriges Ornitologiska Förening, Stockholm.

Söderström B. 2009. Effects of different levels of green- and dead-tree retention on hemi-boreal forest bird communities in Sweden. Forest Ecology and Management 257: 215-222. https://doi.org/10.1016/j. foreco.2008.08.030

Tjernberg M \& Svensson M (eds). 2007. Artfakta - rödlistade ryggradsjur i Sverige. Artdatabanken, SLU, Uppsala.

Virkkala R \& Lehikoinen A. 2017. Birds on the move in the face of climate change: High species turnover in northern Europe. Ecology and Evolution 7: 8201-8829. https://doi.org/10.1002/ece3.3328

Wretenberg J, Lindström Å, Svensson S, Thierfelder T \& Pärt T. 2006. Population trends of farmland birds in Sweden and England: similar trends but different patterns of agricultural intensification. Journal of Applied Ecology 43: 1110-1120. https://doi. org $/ 10.1111 / j .1365-2664.2006 .01216 . x$

WWF. 2018. Living planet report - 2018: Aiming higher. Grooten M \& Almond REA (eds). WWF, Gland, Switzerland.

Zhu Z, Piao S, Myneni RB, Huang M, Zeng Z, Canadell JG, Ciais P, Sitch S, Friedlingstein P, Arneth A, Cao C, Cheng L, Kato E, Koven C, Li Y, Lian X, Liu Y, Liu R, Mao J, Pan Y, Peng S, Peñuelas J, Poulter B, Pugh TAM, Stocker BD, Viovy N, Wang X, Wang Y, Xiao Z, Yang H, Zaehle S \& Zeng N. 2016. Greening of the Earth and its drivers. Nature Climate Change 6: 791-795. https://doi. org/10.1038/nclimate3004

\section{Svensk sammanfattning}

De senaste decennierna har antalet fåglar knutna till skogsmiljö i Sverige ökat. Anledningen till detta är inte helt klarlagd. Ökningar av ytan skog och av tillgången på skogsstrukturer viktiga för biologisk mångfald, samt ett varmare klimat, har alla föreslagits som möjliga och troliga förklaringar. Här undersöker vi denna fråga lite närmare genom att jämföra fågeldata från en lokal vinterpunktrutt runt Storuman i Lappland mellan 1986 och 2017, med regionala skogs- och lokala väderdata.

Regionalt sett minskade ytan av öppen mark och yngre skogar under de senaste årtiondena. Samtidigt ökade ytan med uppvuxen skog, något som främst be- rodde på en ökning av ytan gallringsskog, medelålders skog på mellan 30 och 70 år. Ytan avverkningsmogen skog, >70 år gammal, minskade i stället något. Ytan gammal skog, >140 år gammal, ökade totalt sett. I mer detalj skedde en minskning de första tio åren, följt av en ökning under följande tio åren, varefter ingen större förändring skedde. Volymen av uppvuxen skog ökade, dvs. skogen blev allt tätare och även mängden död ved ökade (Tabell 1). Något förvånande skedde inga förändringar av lokala års-, vinter- eller sommarmedelvärden för temperatur och nederbörd under perioden ( Tabell 2). 
Antalet observerade arter och individer per år av övervintrande fåglar, som under häckningstiden är knutna till skogsmiljö, ökade runt Storuman mellan 1986 och 2017 (Figur 2 och Figur 3). Sammantaget ökade också antalet individer per år av mer specialiserade skogsarter (Figur 4).

En del av ökningen av antalet observerade arter hänger ihop med att några nya arter etablerade sig $\mathrm{i}$ området under studieåren. Nötväckan Sitta europaea sågs för första gången 1995 och har observerades årligen sedan 2007. Gråspetten Picus canus dök upp först 2002 och har sedan setts nästan varje år. Nötkråkan Nucifraga caryocatactes har visat sig flera gånger sedan 2008, då den observerades första gången. Det var inga arter som försvann från området under perioden. Antalet arter visade signifikant positiva samband med ökande yta medelålders skog, stående skogsvolym, volymen död ved och ytan gammal skog, men negativa sådana med ytan kalmark, slutavverkningsmogen skog, och äldre lövrik skog (Figur 6).

Totalt sett registrerades 15907 fåglar av skogsanknutna arter genom åren. De vanligaste arterna var talgoxe Parus major, domherre Pyrrhula pyrrhula, sidensvans Bombycilla garrulus och talltita Poecile montanus. Dessa fyra har var för sig setts i mer än 1000 exemplar totalt. Både de allra vanligaste arterna och de mindre vanliga arterna ökade i antal. De vanligaste arternas andel av det totala antalet sedda faglar varierade mycket mellan åren, men ingen statistiskt säker förändring i denna andel skedde sett över hela perioden. I absoluta tal ökade dock de vanligaste fåglarna mer än de mindre vanliga. Antalet skogsfågelindivider ökade med ökande yta medelålders skog, stående skogsvolym, och volymen död ved, men minskade i antal med ökad yta kalmark, slutaverkningsmogen skog och äldre lövrik skog. Vi fann en tendens till ökat antal skogsfåglar när ytan gammal skog ökade (Figur 6, Bilaga 2).

Av de mer specialiserade skogsarterna, som ställer högre krav på skogens struktur, var talltita den överlägset vanligaste arten och den enda arten som observera- des varje år. Lavskrika Perisoreus infaustus observerades alla år utom ett (2014). De andra skogsspecialistarterna observerades mer oregelbundet. Skogspecialisterna ökade kraftigt de första 20 åren följt av en minskning under de senaste tolv åren, vilket speglar utvecklingen i Sverige som helhet väl. Sett till hela perioden ökade dock antalet skogsspecialister signifikant (Figur 4). Vi fann ökande antal skogspecialister med ökande yta medelålders skog, stående skogsvolym, och mängden död ved, men minskande antal med ökande yta kalmark, slutavverkningsmogen skog och äldre lövrik skog. Något överraskande ökade antalet skogsspecialister inte med ökad yta gammal skog (Figur 6).

Sammansättningen i vinterfaggelsamhället av skogsanknutna arter kring Storuman, uttryckt som fagelsamhällets temperaturindex (Community Temperature Index, CTI), visade att skogsanknutna faglar arter med varmare utbredningsområden under häckningstid blev relativt sett vanligare jämfört med skogsfåglar som tillhör arter med kallare häckningsområden under de 32 åren (Figur 5). CTI visade dock inga samband med antalet observerade skogsfaglar. CTI visade inte heller några generella samband med väder, annat än att CTI ökade med minskande mängd vinternederbörd (Tabell 3).

Sammanfattningsvis kan sägas att eftersom varken medeltemperatur eller medelnederbörd förändrades under studieperioden kan dessa variabler inte förklara den allmänna ökningen av vinterfåglar av skogsanknutna arter runt Storuman. För de ökande antal individer, arter och skogspecialister hittade vi i stället tydliga korrelationer med ytan uppvuxen - främst medelålders - skog, tätare uppvuxna skogar, ökad volym död ved och minskade områden med öppen, nyligen avverkad, mark och ungskog. Även om det kan finnas andra förklaringar bakom det ökande antalet skogsfåglar, såsom minskat jordbruk, minskande lokalbefolkning eller starkare fotosyntes, tyder våra resultat på att regional markanvändning runt Storuman har varit gynnsam för skogsfåglar under de senaste årtiondena.

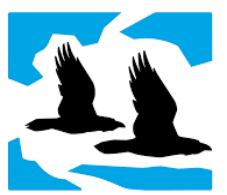

Birdlife Sverige

Ornis Svecica (ISSN 2003-2633) is an open access, peer-reviewed scientific journal published in English and Swedish by BirdLife Sweden. It covers all aspects of ornithology, and welcomes contributions from scientists as well as non-professional ornithologists. Accepted articles are published at no charge to the authors. Read papers or make a submission at os.birdlife.se.

Ornis Svecica (ISSN 2003-2633) är en fritt tillgänglig granskad vetenskaplig tidskrift som ges ut på svenska och engelska av BirdLife Sverige. Den täcker ornitologins alla områden och välkomnar bidrag från såväl forskare som icke-professionella ornitologer. Accepterade uppsatser publiceras utan kostnad för författarna. Läs uppsatser eller skicka in ditt bidrag på os.birdlife.se. 


\section{Appendix 1. Annual count data}

\begin{tabular}{|c|c|c|c|c|c|c|c|c|c|c|c|c|c|c|c|c|c|c|c|}
\hline \multicolumn{3}{|c|}{ Species Art } & \multirow[b]{3}{*}{1986} & \multirow[b]{3}{*}{1987} & \multirow[b]{3}{*}{1988} & \multirow[b]{3}{*}{1989} & \multirow[b]{3}{*}{1990} & \multirow[b]{3}{*}{1991} & \multirow[b]{3}{*}{1992} & \multirow[b]{3}{*}{1993} & \multirow[b]{3}{*}{1994} & \multirow[b]{3}{*}{1995} & \multirow[b]{3}{*}{1996} & \multirow[b]{3}{*}{1997} & \multirow[b]{3}{*}{1998} & \multirow[b]{3}{*}{1999} & \multirow[b]{3}{*}{2000} & \multirow[b]{3}{*}{2001} & \multirow[b]{3}{*}{2002} \\
\hline English name & Swedish name & Scientfic name & & & & & & & & & & & & & & & & & \\
\hline Engelskt namn & Svenskt namn & Vetenskapligt namn & & & & & & & & & & & & & & & & & \\
\hline Golden Eagle & kungsörn & Aquila chrysaetos & 1 & & & & & & & & & 3 & & & & & & 1 & \\
\hline Northern Goshawk & duvhök & Accipiter gentilis & & & & & 1 & & & & 1 & & & & & 1 & & & \\
\hline Black Grouse & orre & Lyrurus tetrix & 20 & 6 & 2 & 21 & 12 & 9 & 11 & 5 & 34 & 26 & 39 & 8 & 52 & 18 & 10 & 13 & 69 \\
\hline Western Capercaillie & tjäder & Tetrao urogallus & & & & & & & & & 1 & & & & 1 & & 1 & & 1 \\
\hline Hazel Grouse & järpe & Tetrastes bonasia & 5 & & & & 3 & 1 & & 2 & 1 & 1 & & & & 2 & & & 8 \\
\hline Northern Hawk Owl & hökuggla & Surnia ulula & & & & 1 & 3 & & & & & & & & & & & & \\
\hline Eurasian Pygmy Owl & sparvuggla & Glaucidium passerinum & & & & & & 1 & & 1 & & & & 1 & & & 1 & & \\
\hline $\begin{array}{l}\text { Grey-headed Wood- } \\
\text { pecker }\end{array}$ & gråspett & Picus canus & & & & & & 1 & & & & & & & & & & & 2 \\
\hline $\begin{array}{l}\text { Great Spotted Wood- } \\
\text { pecker }\end{array}$ & $\begin{array}{l}\text { större } \\
\text { hackspett }\end{array}$ & Dendrocopus major & 9 & & 15 & 6 & 4 & 6 & 5 & 6 & 1 & & 3 & 3 & 5 & 3 & 4 & 4 & 6 \\
\hline $\begin{array}{l}\text { Lesser Spotted } \\
\text { Woodpecker }\end{array}$ & $\begin{array}{l}\text { mindre } \\
\text { hackspett }\end{array}$ & Dendrocopus minor & & & & & & & & & & & & & & & & & \\
\hline $\begin{array}{l}\text { Eurasian Three-toed } \\
\text { Woodpecker }\end{array}$ & $\begin{array}{l}\text { tretåig } \\
\text { hackspett }\end{array}$ & Picoides tridactylus & & & 3 & & 2 & & 1 & & & & & & & & & & \\
\hline Black Woodpecker & spillkråka & Dryocopus major & & & 1 & & 2 & & & & & & & & & 1 & & 1 & \\
\hline Northern Raven & korp & Corus corax & 9 & 4 & 17 & 22 & 9 & 64 & 16 & 8 & 16 & 13 & 14 & 8 & 60 & 7 & 12 & 19 & 23 \\
\hline Spotted Nutcracker & nötkråka & Nucifraga caryocatactes & & & & & & & & & & & & & & & & & \\
\hline Eurasian Jay & nötskrika & Garrulus glandarius & 8 & 6 & 9 & 3 & 7 & 7 & 9 & 2 & 4 & 3 & 5 & 2 & 8 & 6 & 5 & 7 & 11 \\
\hline Siberian Jay & lavskrika & Perisoreaus infaustus & 10 & 1 & 6 & 4 & 3 & 6 & 4 & 6 & 5 & 8 & 11 & 5 & 11 & 3 & 4 & 5 & 9 \\
\hline Long-tailed Tit & stjärtmes & Aegithalos caudatus & & & 2 & & & & & & & & & & & & & & \\
\hline Great Tit & talgoxe & Parus major & 92 & 73 & 98 & 82 & 143 & 115 & 143 & 104 & 139 & 98 & 144 & 121 & 178 & 125 & 117 & 164 & 129 \\
\hline Eurasian Blue tit & blåmes & Cyanistes caeruleus & 6 & 5 & 9 & 5 & 1 & 7 & 10 & 7 & 11 & 9 & 9 & 8 & 3 & 12 & 10 & 10 & 18 \\
\hline Coal Tit & svartmes & Periparus ater & & & & & 6 & 6 & 9 & 6 & 2 & & & & 2 & & 1 & 1 & 2 \\
\hline Grey-headed Chickadee & lappmes & Poecile cinctus & & & & & 2 & & & 1 & & & & & & & 1 & 2 & \\
\hline Willow Tit & talltita & Poecile montanus & 43 & 51 & 43 & 24 & 39 & 65 & 75 & 59 & 69 & 57 & 79 & 65 & 95 & 79 & 93 & 75 & 73 \\
\hline
\end{tabular}


APPENDIX 1 continued | Appendix 1 fortsatt.

\begin{tabular}{|c|c|c|c|c|c|c|c|c|c|c|c|c|c|c|c|c|c|c|}
\hline \multicolumn{3}{|c|}{ Species Art } & \multirow[b]{2}{*}{2003} & \multirow[b]{2}{*}{2004} & \multirow[b]{2}{*}{2005} & \multirow[b]{2}{*}{2006} & \multirow[b]{2}{*}{2007} & \multirow[b]{2}{*}{2008} & \multirow[b]{2}{*}{2009} & \multirow[b]{2}{*}{2010} & \multirow[b]{2}{*}{2011} & \multirow[b]{2}{*}{2012} & \multirow[b]{2}{*}{2013} & \multirow[b]{2}{*}{2014} & \multirow[b]{2}{*}{2015} & \multirow[b]{2}{*}{2016} & \multirow[b]{2}{*}{2017} & \multirow[b]{2}{*}{ Sum } \\
\hline $\begin{array}{l}\text { English name } \\
\text { Engelskt namn }\end{array}$ & $\begin{array}{l}\text { Swedish name } \\
\text { Svenskt namn }\end{array}$ & $\begin{array}{l}\text { Scientfic name } \\
\text { Vetenskapligt namn }\end{array}$ & & & & & & & & & & & & & & & & \\
\hline Golden Eagle & kungsörn & Aquila chrysaetos & & 3 & & 1 & 1 & & & & 1 & & & & 1 & 1 & & 13 \\
\hline Northern Goshawk & duvhök & Accipiter gentilis & & & & & & & 1 & & & & & & & & & 4 \\
\hline Black Grouse & orre & Lyrurus tetrix & 6 & 12 & 6 & 1 & 11 & 69 & 28 & 19 & 23 & 3 & 1 & & 3 & 8 & 9 & 554 \\
\hline Western Capercaillie & tjäder & Tetrao urogallus & & & & 2 & 1 & & 1 & & 2 & 1 & & & 1 & 1 & & 13 \\
\hline Hazel Grouse & järpe & Tetrastes bonasia & 6 & 2 & & 1 & 1 & 6 & & 2 & 1 & 2 & & 1 & 2 & & 1 & 48 \\
\hline Northern Hawk Owl & hökuggla & Surnia ulula & & 1 & & & & & & & 1 & & 2 & & & & & 8 \\
\hline Eurasian Pygmy Owl & sparvuggla & Glaucidium passerinum & & & 1 & 1 & & & & & & & & & & & & 6 \\
\hline $\begin{array}{l}\text { Grey-headed Wood- } \\
\text { pecker }\end{array}$ & gråspett & Picus canus & & 3 & & 1 & 3 & 6 & 3 & 4 & 1 & 2 & 2 & 2 & 1 & & & 31 \\
\hline $\begin{array}{l}\text { Great Spotted Wood- } \\
\text { pecker }\end{array}$ & $\begin{array}{l}\text { större } \\
\text { hackspett }\end{array}$ & Dendrocopus major & 7 & 15 & 16 & 22 & 7 & 23 & 14 & 23 & 14 & 8 & 16 & 19 & 33 & 6 & 10 & 313 \\
\hline $\begin{array}{l}\text { Lesser Spotted } \\
\text { Woodpecker }\end{array}$ & $\begin{array}{l}\text { mindre } \\
\text { hackspett }\end{array}$ & Dendrocopus minor & & & & & & & & & & 1 & & & & & & 1 \\
\hline $\begin{array}{l}\text { Eurasian Three-toed } \\
\text { Woodpecker }\end{array}$ & $\begin{array}{l}\text { tretåig } \\
\text { hackspett }\end{array}$ & Picoides tridactylus & 1 & & 1 & & & & & 2 & & & & 1 & & & & 11 \\
\hline Black Woodpecker & spillkråka & Dryocopus major & 1 & 1 & & 2 & 1 & & 2 & & & & & 1 & & & & 13 \\
\hline Northern Raven & korp & Corus corax & 14 & 28 & 10 & 28 & 43 & 9 & 14 & 21 & 16 & 17 & 18 & 16 & 15 & 11 & 16 & 597 \\
\hline Spotted Nutcracker & nötkråka & Nucifraga caryocatactes & & & & & & 2 & & 1 & & 15 & 2 & & & 1 & & 21 \\
\hline Eurasian Jay & nötskrika & Garrulus glandarius & 5 & 8 & 9 & 17 & 14 & 5 & 4 & 15 & 10 & 15 & 17 & 9 & 11 & 9 & 12 & 262 \\
\hline Siberian Jay & lavskrika & Perisoreaus infaustus & 10 & 7 & 12 & 10 & 12 & 9 & 7 & 4 & 5 & 6 & 4 & & 5 & 1 & 8 & 201 \\
\hline Long-tailed Tit & stjärtmes & Aegithalos caudatus & & & 12 & & & & & & & 15 & & & & & & 29 \\
\hline Great Tit & talgoxe & Parus major & 169 & 190 & 142 & 229 & 179 & 127 & 208 & 255 & 212 & 286 & 241 & 271 & 202 & 229 & 206 & 5,211 \\
\hline Eurasian Blue tit & blåmes & Cyanistes caeruleus & 14 & 11 & 26 & 29 & 36 & 29 & 35 & 37 & 38 & 35 & 41 & 32 & 36 & 36 & 22 & 597 \\
\hline Coal Tit & svartmes & Periparus ater & 4 & 2 & & 1 & 1 & 1 & 1 & & & 1 & & 2 & 1 & & 1 & 50 \\
\hline Grey-headed Chickadee & lappmes & Poecile cinctus & & & & & & & & & & & & & & & & 6 \\
\hline Willow Tit & talltita & Poecile montanus & 110 & 93 & 93 & 136 & 100 & 66 & 96 & 113 & 98 & 77 & 128 & 104 & 60 & 88 & 64 & 2,510 \\
\hline
\end{tabular}


APPENDIX 1 continued | Appendix 1 fortsatt.

\begin{tabular}{|c|c|c|c|c|c|c|c|c|c|c|c|c|c|c|c|c|c|c|c|}
\hline \multicolumn{3}{|c|}{ Species Art } & \multirow[b]{3}{*}{1986} & \multirow[b]{3}{*}{1987} & \multirow[b]{3}{*}{1988} & \multirow[b]{3}{*}{1989} & \multirow[b]{3}{*}{1990} & \multirow[b]{3}{*}{1991} & \multirow[b]{3}{*}{1992} & \multirow[b]{3}{*}{1993} & \multirow[b]{3}{*}{1994} & \multirow[b]{3}{*}{1995} & \multirow[b]{3}{*}{1996} & \multirow[b]{3}{*}{1997} & \multirow[b]{3}{*}{1998} & \multirow[b]{3}{*}{1999} & \multirow[b]{3}{*}{2000} & \multirow[b]{3}{*}{2001} & \multirow[b]{3}{*}{2002} \\
\hline English name & Swedish name & Scientfic name & & & & & & & & & & & & & & & & & \\
\hline Engelskt namn & Svenskt namn & Vetenskapligt namn & & & & & & & & & & & & & & & & & \\
\hline Eurasian Nuthatch & nötväcka & Sitta europea & & & & & & & & & & 2 & & & & 1 & & & \\
\hline Eurasian Treecreeper & trädkrypare & Certhia familiaris & & & 1 & & & & & & & 1 & & & 1 & & & & \\
\hline Mistle Thrush & dubbeltrast & Turdus viscivorus & & & & & & & & & & & & & & & & & 1 \\
\hline Fieldfare & björktrast & Turdus pilaris & & 2 & & 1 & & 2 & 6 & 1 & & 4 & 2 & 8 & 1 & 19 & 12 & & 3 \\
\hline Redwing & rödvingetrast & Turdus iliacus & & & & & & 2 & & & & 1 & & & & & & & \\
\hline Common Blackbird & koltrast & Turdus merula & & & & & & & & & & & & & & & & & \\
\hline Eurasian Blackcap & svarthätta & Sylvia atricapilla & & 1 & & & & & & & & & & & & & & & \\
\hline Goldcrest & kungsfågel & Regulus regulus & & & 2 & & & & 2 & & & & & & 1 & & & & \\
\hline Bohemian waxwing & sidensvans & Bombycilla garrulus & & 13 & 11 & 43 & 9 & 121 & 155 & & & 13 & 2 & 81 & 28 & 27 & 39 & & 232 \\
\hline Hawfinch & stenknäck & $\begin{array}{l}\text { Coccothraustes } \\
\text { coccothraustes }\end{array}$ & & & & 2 & & & & & & & & & & & & & \\
\hline Eurasian Bullfinch & domherre & Pyrrhula pyrrhula & 46 & 43 & 68 & 69 & 25 & 62 & 39 & 112 & 74 & 60 & 36 & 82 & 84 & 73 & 40 & 45 & 182 \\
\hline Pine Grosbeak & tallbit & Pinicola enucleator & 3 & & 4 & 2 & & & 5 & & 10 & 1 & 1 & & 2 & & 1 & & 41 \\
\hline Red / Parrot Crossbill & $\begin{array}{l}\text { mindre / större } \\
\text { korsnäbb }\end{array}$ & $\begin{array}{l}\text { Loxia curvirostrata / } \\
\text { pytopsittacus }\end{array}$ & 62 & & 1 & 56 & & 5 & 70 & & & 75 & & 6 & & 2 & 3 & & 12 \\
\hline Two-barred Crossbill & $\begin{array}{l}\text { bän- } \\
\text { delkorsnäbb }\end{array}$ & Loxia leucoptera & & & & & & & & & & 3 & & & & & & & \\
\hline Common chaffinch & bofink & Fringilla coelebs & & & & & & & & & & & & & & & & & \\
\hline Brambling & bergfink & Fringilla montifringilla & & & & & & & & & & & & & & & & & \\
\hline Total & totalt & & 314 & 205 & 292 & 343 & 271 & 480 & 560 & 320 & 368 & 378 & 345 & 398 & 532 & 379 & 354 & 347 & 822 \\
\hline
\end{tabular}


APPENDIX 1 continued | Appendix 1 fortsatt.

\begin{tabular}{|c|c|c|c|c|c|c|c|c|c|c|c|c|c|c|c|c|c|c|}
\hline \multirow[b]{2}{*}{$\begin{array}{l}\text { English name } \\
\text { Engelskt namn }\end{array}$} & \multicolumn{2}{|l|}{ Species Art } & \multirow[b]{2}{*}{2003} & \multirow[b]{2}{*}{2004} & \multirow[b]{2}{*}{2005} & \multirow[b]{2}{*}{2006} & \multirow[b]{2}{*}{2007} & \multirow[b]{2}{*}{2008} & \multirow[b]{2}{*}{2009} & \multirow[b]{2}{*}{2010} & \multirow[b]{2}{*}{2011} & \multirow[b]{2}{*}{2012} & \multirow[b]{2}{*}{2013} & \multirow[b]{2}{*}{2014} & \multirow[b]{2}{*}{2015} & \multirow[b]{2}{*}{2016} & \multirow[b]{2}{*}{2017} & \multirow[b]{2}{*}{ Sum } \\
\hline & $\begin{array}{l}\text { Swedish name } \\
\text { Svenskt namn }\end{array}$ & $\begin{array}{l}\text { Scientfic name } \\
\text { Vetenskapligt namn }\end{array}$ & & & & & & & & & & & & & & & & \\
\hline Eurasian Nuthatch & nötväcka & Sitta europea & 2 & & & & 3 & 3 & 4 & 3 & 9 & 4 & 2 & 5 & 6 & 6 & 10 & 60 \\
\hline Eurasian Treecreeper & trädkrypare & Certhia familiaris & & & & & & & & & & 1 & & 2 & & 1 & & 7 \\
\hline Mistle Thrush & dubbeltrast & Turdus viscivorus & & & & & & & & & & & & & & 1 & & 2 \\
\hline Fieldfare & björktrast & Turdus pilaris & & & 4 & 1 & & 18 & 1 & & 7 & 1 & & 7 & & 2 & 25 & 127 \\
\hline Redwing & rödvingetrast & Turdus iliacus & & & 5 & & & & & & & & & & & & 1 & 9 \\
\hline Common Blackbird & koltrast & Turdus merula & & & & & & & 1 & & & & & 1 & & & & 2 \\
\hline Eurasian Blackcap & svarthätta & Sylvia atricapilla & & & & & & & & & & & & & & & & 1 \\
\hline Goldcrest & kungsfågel & Regulus regulus & & & & & & 5 & & & & 2 & & & & 2 & & 14 \\
\hline Bohemian waxwing & sidensvans & Bombycilla garrulus & & & 4 & 25 & & 42 & & 11 & & 2 & & 83 & & 9 & 128 & 1,078 \\
\hline Hawfinch & stenknäck & $\begin{array}{l}\text { Coccothraustes } \\
\text { coccothraustes }\end{array}$ & & & & & & & & & & & & & & & & 2 \\
\hline Eurasian Siskin & grönsiska & Carduelis spinus & & & & & & & & & & & & 1 & 1 & & & 4 \\
\hline Eurasian Bullfinch & domherre & Pyrrhula pyrrhula & 134 & 34 & 93 & 108 & 121 & 144 & 132 & 99 & 88 & 229 & 207 & 250 & 162 & 146 & 329 & 3,416 \\
\hline Pine Grosbeak & tallbit & Pinicola enucleator & 22 & & & & & & & & & & & 3 & & & 1 & 96 \\
\hline Red / Parrot Crossbill & $\begin{array}{l}\text { mindre / större } \\
\text { korsnäbb }\end{array}$ & $\begin{array}{l}\text { Loxia curvirostrata / } \\
\text { pytopsittacus }\end{array}$ & & 102 & 2 & 62 & & 2 & & 92 & & 2 & & & 19 & & & 573 \\
\hline Two-barred Crossbill & $\begin{array}{l}\text { bän- } \\
\text { delkorsnäbb }\end{array}$ & Loxia leucoptera & & & & & & & & 5 & & & & & & & & 8 \\
\hline Common chaffinch & bofink & Fringilla coelebs & & & & 1 & 2 & & & & 1 & & & 1 & & 1 & & 6 \\
\hline Brambling & bergfink & Fringilla montifringilla & & 1 & & & & & & & & & & & & 1 & 1 & 3 \\
\hline Total & totalt & & 505 & 513 & 436 & 678 & 536 & 566 & 552 & 706 & 527 & 725 & 681 & 811 & 559 & 560 & 844 & 15,907 \\
\hline
\end{tabular}




\section{Appendix 2. Full correlations between bird and forest variables}

\begin{tabular}{|c|c|c|c|c|c|c|}
\hline \multirow{3}{*}{$\begin{array}{l}\text { Forest variable Skogsvariabel } \\
\text { Open ground, area Öppen mark, yta }\end{array}$} & \multicolumn{6}{|c|}{$r_{s}$, significance } \\
\hline & \multicolumn{2}{|c|}{$\begin{array}{l}\mathrm{N} \text { forest species } \\
\text { Antal skogsarter }\end{array}$} & \multicolumn{2}{|c|}{$\begin{array}{l}\mathrm{N} \text { ind, forest species } \\
\text { Antal ind, skogsarter }\end{array}$} & \multicolumn{2}{|c|}{$\begin{array}{l}\mathrm{N} \text { ind, forest specialists } \\
\text { Antal ind, skogsspecialister }\end{array}$} \\
\hline & -0.45 & ** & -0.80 & ** & -0.60 & ** \\
\hline $\begin{array}{l}\text { Young forest ( } 0-30 \text { years), area } \\
\text { Ung skog (0-30 år), yta }\end{array}$ & -0.20 & NS & -0.42 & * & -0.11 & NS \\
\hline $\begin{array}{l}\text { Middle-aged forest ( } 30-70 \text { years), area } \\
\text { Medelàlders skog ( } 30-70 \text { år), yta }\end{array}$ & 0.46 & ** & 0.75 & $* \star *$ & 0.54 & $\star \star$ \\
\hline $\begin{array}{l}\text { Forest ready for cutting (>70 years), area Avverkning- } \\
\text { smogen skog (>70 år), yta }\end{array}$ & -0.34 & * & -0.67 & $* * *$ & -0.53 & ** \\
\hline $\begin{array}{l}\text { Fully grown forest (middle-aged + ready for cutting; } \\
>30 \text { years), area Fullt uppvuxen skog (medelålders + } \\
\text { avverkningsmogen; > } 30 \text { år), yta }\end{array}$ & 0.31 & $(*)$ & 0.23 & NS & 0.15 & NS \\
\hline $\begin{array}{l}\text { Old forest (>140 years), area } \\
\text { Gammal skog (>140 år), yta }\end{array}$ & 0.39 & * & 0.38 & $(*)$ & 0.21 & NS \\
\hline $\begin{array}{l}\text { Older forest, rich in deciduous trees (>80 years), area } \\
\text { Äldre lövträdsrik skog (>80 år), yta }\end{array}$ & -0.37 & (*) & -0.73 & $* \star *$ & -0.47 & * \\
\hline $\begin{array}{l}\text { Standing volume of wood in middle-aged forest } \\
\text { Stående skogsvolym i medelålders skog }\end{array}$ & 0.43 & * & 0.71 & $* * *$ & 0.50 & $* *$ \\
\hline $\begin{array}{l}\text { Standing volume of wood in forest ready for cutting } \\
\text { Stående skogsvolym i avverknoingsmogen skog }\end{array}$ & 0.37 & * & 0.72 & $* * *$ & 0.53 & $* *$ \\
\hline $\begin{array}{l}\text { Standing volume of wood in fully grown forest } \\
\text { Stående skogsvolym i fullt uppvuxen skog }\end{array}$ & 0.40 & * & 0.76 & $* \star *$ & 0.52 & ** \\
\hline Dead wood, volume Död ved, volym & 0.39 & * & 0.65 & $\star \star \star *$ & 0.39 & * \\
\hline
\end{tabular}

\section{Appendix 3. Full correlations between bird and weather variables}

\begin{tabular}{|c|c|c|c|c|c|c|}
\hline \multirow{3}{*}{$\begin{array}{l}\text { Weather variable Vädervariabel } \\
\text { Annual temperature (April-March) } \\
\text { Arstemperatur (april-mars) }\end{array}$} & \multicolumn{6}{|c|}{$r_{s}$, significance } \\
\hline & \multicolumn{2}{|c|}{$\begin{array}{l}\mathrm{N} \text { forest species } \\
\text { Antal skogsarter }\end{array}$} & \multicolumn{2}{|c|}{$\begin{array}{l}\mathrm{N} \text { ind, forest species } \\
\text { Antal ind, skogsarter }\end{array}$} & \multicolumn{2}{|c|}{$\begin{array}{l}\mathrm{N} \text { ind, forest specialists } \\
\text { Antal ind, skogsspecialister }\end{array}$} \\
\hline & 0.18 & NS & 0.08 & NS & 0.22 & NS \\
\hline $\begin{array}{l}\text { Winter temperature (November-March) } \\
\text { Vintertemperatur (november-mars) }\end{array}$ & 0.07 & NS & -0.01 & NS & 0.07 & NS \\
\hline $\begin{array}{l}\text { Summer temperature (April-August) } \\
\text { Sommartemperatur (april-augusti) }\end{array}$ & 0.24 & NS & 0.17 & NS & 0.47 & $* *$ \\
\hline $\begin{array}{l}\text { Annual precipitation (April-March) } \\
\text { Arsnederbörd (april-mars) }\end{array}$ & -0.27 & NS & -0.21 & NS & 0.10 & NS \\
\hline $\begin{array}{l}\text { Winter precipitation (November-March) } \\
\text { Vinternederbörd (november-mars) }\end{array}$ & -0.36 & * & -0.30 & $(*)$ & -0.10 & NS \\
\hline $\begin{array}{l}\text { Summer precipitation (April-August) } \\
\text { Sommarnederbörd (april-augusti) }\end{array}$ & -0.20 & NS & -0.23 & NS & -0.10 & NS \\
\hline
\end{tabular}

